\title{
From Political Instrument to Protection Tool? Resettlement of Refugees and North-South Relations
}

\author{
Thais Bessa
}

\begin{abstract}
Lacking a clear legal definition, the conceptualization and application of durable solutions have been highly influenced by states' interests that were often at odds with humanitarian concerns on refugee protection. During the Cold War resettlement was perceived as the preferred durable solution, although it was selectively applied to different refugee crises in the South. With the asylum crisis in the 1980s and the end of the Cold War, a new agenda of containment emerged as Northern countries' interest in receiving refugees declined. During the 1990 s voluntary repatriation emerged as a new preferred solution and there was an effort to redefine and adapt resettlement to a new context. This process focused on detaching resettlement from its previous political and immigration character and redefining it as an exclusive protection tool and instrument of international co-operation. Hence, resettlement in the post-Cold War era is characterized by depoliticization, a smaller number of beneficiaries, and geographic expansion. However, it is important to critically question whether such depoliticization has happened in fact, the reasons behind it, and its relation to North-South politics and containment strategies.
\end{abstract}

\section{Résumé}

Faute d'une définition juridique claire, la conceptualisation et l'application de solutions durables à la réinstallation ont été fortement influencées par des intérêts étatiques souvent en contradiction avec les préoccupations humanitaires sur la protection des réfugiés. Durant la guerre froide, la réinstallation paraissait la solution durable la plus souhaitable, bien qu'appliquée de façon ponctuelle aux différentes crises de réfugiés dans le Sud. Un nouveau programme de confinement apparaît lors de la crise de l'asile des années 1980 et la fin de la guerre froide quand diminue la volonté des pays du Nord à accueillir les demandeurs d'asile. Le rapatriement volontaire apparaît au cours des années 1990 comme nouvelle solution de préférence. On tente alors de redéfinir la réinstallation et de l'adapter au nouveau contexte. Ce processus est axé sur une rupture de la réinstallation avec ses aspects politique et migratoire précédents et sa redéfinition en tant qu'outil exclusif de protection et instrument de la coopération internationale. Ainsi, la réinstallation à l'ère de l'après-guerre froide se caractérise par la dépolitisation, la réduction du nombre de bénéficiaires et l'expansion géographique. Toutefois, il est essentiel de déterminer de façon critique si cette dépolitisation s'est réellement faite, les raisons qui la sous-tendent et sa relation à la politique Nord-Sud et aux stratégies de confinement.

\section{Introduction}

Research and policy making in forced migration commonly refer to the concept of durable solutions and its three options: local integration, resettlement, and voluntary repatriation. However, these concepts find loose support from legal instruments and are mainly derived from the regular practice of states and international organizations. Consequently, they are embedded in a complex set of political, economic, and strategic interests that often go far beyond humanitarian concerns on refugees' protection. In that sense, the use of resettlement, especially in North-South relations, has changed from the Cold War period to the present, allegedly evolving from a political instrument to a protection tool. The present paper will examine the question that although the very concept of "refugee" is intimately linked to political upheavals and interests, the way refuges have been dealt with (i.e. the durable solutions offered) has been influenced by different explicit and implicit interests that have varied over time in speech and practice. 
As the present refugee regime was initially designed in the early days of the Cold War, the lack of a precise definition of durable solutions and the relationship between them enabled states to manipulate their use according to political, economic, and ideological interests. Hence, during the early 1950 s, resettlement was praised as not only the preferred durable solution, but the only viable one, and it played an important role in transferring refugee populations from communist countries.

In the following decades forced displacement increased dramatically in the global South, and the responses provided to refugee influxes continued to be highly embedded in Cold War political and strategic interests, so that different refugee crises received differing "solutions." With the end of the Cold War and the asylum crisis initiated in the late 1970s and early 1980s, Northern states had a declining interest in receiving refugees. Consequently, containment strategies gained importance and during the late 1980s and 1990s there was a process to redefine durable solutions available to refugees.

In this process, voluntary repatriation replaced resettlement as the preferred durable solution and there were consistent efforts to detach resettlement from its previous feature of a political and migration instrument and (re)define it as a protection tool. Under this approach resettlement would serve a smaller number of refugees, but would obey strict protection criteria that uphold the safety and welfare of refugees.

If resettlement lost space in a containment context, why was it never abandoned by states and international organizations? First of all, even though the United Nations High Commissioner for Refugees (UNHCR) had a crucial role in advocating for voluntary repatriation as the preferred durable solution, it also attempted to maintain resettlement as an option available through a process to redefine it and adapt it to new circumstances. An important consequence of this process was the focus on protection and international co-operation, culminating in an expansion of resettlement to the global South.

Second, even in a containment context, Northern countries still receive refugees due to different reasons, including political and foreign policy interests, domestic pressure, economic interests, and humanitarian concern. More important, amidst accusations of uncontrolled immigrants' and asylum-seekers' entry, resettlement enables states to regain control over refugee admission.

It can be argued that redefining resettlement exclusively as a protection tool was exactly what enabled its continued use, geographically expanded yet numerically reduced. However, one can critically analyze the motivations behind it, whether such depoliticization actually happened, and how it impacted refugee issues in North-South relations. In that sense, the UNHCR-led process to redefine resettlement was an effort to reposition durable solutions in line with changing interests of states. Moreover, resettlement is still applied according interests that are not purely humanitarian or protection, as different refugee populations receive different solutions. Finally, although emerging resettlement programs in the South are praised as the best example of resettlement as a protection tool, it is important to situate them in broader North-South relations and containment strategies.

The paper has six sections. The first examines how the resettlement concept, in the absence of legal instruments, was forged and promoted as the most desirable solution in the early days of the Cold War. The following section will show how the political use of resettlement evolved along with the Cold War and how it was selectively applied to distinct situations. The third part briefly explains the asylum crisis experienced in the late 1970s and 1980s and how it affected the conceptualization of durable solutions and resettlement. Section four will analyze the effort to redefine durable solutions and the relationship between them, focusing on the process of depoliticizing resettlement. The next part will examine the characteristics of resettlement in the post-Cold War era and how they differ from previous years. The final section will analyze the complex set of factors that explain why Northern countries continue to use resettlement even in a context of containment and decreasing interest in international co-operation. The paper will conclude with some final critical remarks and challenges for the future.

\section{Defining Resettlement during the Early Cold War: The Preferred Solution}

The International Thesaurus of Refugee Terminology $\left(\right.$ ITRT) ${ }^{1}$ defines "resettlement" as "the durable settlement of refugees in a country other than the country of refuge." However, it should be noted that such definition is derived from the practice of states and UNHCR guidelines rather than an international legal instrument. The milestone of refugee protection, the 1951 Convention relating to the Status of Refugees, is silent on a precise definition not only of resettlement, but of the three-fold durable solutions concept as a whole. Resettlement is mentioned only in Article 30, claiming that states should facilitate the transfer of assets of resettled refugees.

A precise definition of resettlement is also lacking in the UNHCR 1950 Statute. As per its Article 1, the agency is mandated to seek permanent solutions for refugees, such as "the voluntary repatriation of such refugees, or their assimilation within new national communities." However, it is open to interpretation whether the last part refers to both

(C) Thais Bessa, 2009. This open-access work is licensed under a Creative Commons Attribution-NonCommercial 4.0 International License, which permits use, reproduction and distribution in any medium for non-commercial purposes, provided the original author(s) are credited and the original publication in Refuge: Canada's Journal on Refugees is cited. 
local integration in the first country of asylum and resettlement in a third country.

Lacking a clear definition, resettlement has been manipulated as a major tool for states to apply discretionary policies, according to interests that are often at odds with the concern with refugees' protection. Specific political and economic interests in a given time shaped the concepts and solutions provided to refugees, which proved to be very flexible regarding different populations and different periods.

As the refugee regime was tailored at the beginning of the Cold War with a strong Eurocentric character, ${ }^{2}$ repatriation was obviously not an option. Resettlement was then the perfect durable solution for refugees due to the combination of strategic interests (recovery and regional stability in Europe), economic interests (immigrant workforce), and ideological interests (supporting defection from Communist states). ${ }^{3}$ Moreover, the US leadership had an important role in this system, as it was willing and able to bear the bulk of costs related to the reception of refugees, offering large resettlement quotas and promoting a similar welcoming position from other Western governments.

During the 1950s and early 1960s resettlement had two main characteristics. First, it bypassed UNHCR because at the beginning it was perceived that the agency's clients were only the refugees displaced by the war who still remained in Europe. The US had a great interest in closely managing the resettlement of refugees from communist countries, and it did so through two different agencies: the Intergovernmental Committee for European Migration (ICEM, created in 1951) and the United States Escapee Program (USEP, officially established in 1952, although it had operated since 1949). Differently from UNHCR in its early days, those agencies received full funding from the US. ${ }^{4}$

Second, resettlement activities were totally concentrated in Europe. During the Berlin crisis in 1953 and throughout the decade until the Berlin Wall was built in 1961, some 3.5 million people fled from East to West Germany and some were resettled farther away. The largest refugee crisis of this period and the first massive resettlement operation occurred after the Soviet invasion of Hungary in 1956. Although the US was initially reluctant to resettle refugees from Yugoslavia, a communist country of first asylum, a total of some 180,000 Hungarian were resettled in thirtyseven countries. ${ }^{5}$ The receptiveness was explained both by Cold War political and ideological interests and economic interests, since the Hungarians were a "model immigration group" composed of skilled workers. ${ }^{6}$

It is important to note that during the Hungarian crisis UNHCR played an important role and began to be recognized by the US as a relevant actor in the bipolar context.
Since then the US government started to contribute financially to UNHCR, becoming its major donor and enabling the agency to expand its personnel and capacity in the following decades.

\section{Resettlement and Cold War Politics in the Global South}

During the late 1960s and the 1970s the decolonization process caused conflicts and massive displacement in the global South, especially in Africa and Asia, which ultimately altered the focus of refugee protection. According to Loescher, "by 73 , the US began to refocus its refugee programs from Europe to the rest of the world, following the global expansion of its foreign policy and security commitments." 7

As refugee influxes and global responses to them started to shift into the South, resettlement remained an important solution. However, its use in specific refugee crises was shaped by economic and principally by political interests of Northern states. This can be exemplified by the analysis of three major refugee crises during the 1970s: in Uganda, the Southern Cone of Latin America, and Indochina.

In 1972 the Ugandan president Idi Amin decided to expel all people of Asian derivation. As a consequence, more than 40,000 people fled the country, including some 7,000 made stateless. UNHCR's appeal for resettlement quotas received a quick and welcoming response from the international community and by the end of 1974 all expelled persons were resettled in twenty-five different countries. ${ }^{8}$

In the same period a refugee crisis erupted in the Southern Cone of Latin America as almost all countries in the region were under authoritarian military governments. More than 200,000 refugees fled Chile after the military coup in 1973, including refugees who were living there after escaping from similar coups in neighbouring countries. ${ }^{9}$ As military regimes in different countries were allied, refugees were targeted in the whole region and there was no safe haven. Therefore, the solution sought for those refugees was predominantly resettlement outside South America, and the UNHCR's appeals were generously answered by European countries. ${ }^{10}$

Nevertheless, the same attitude was not observed from the US, since those refugees were fleeing Washingtonsupported regimes, under accusations of Communist affiliation. "The US virtually ignored appeals for resettlement and it even refused to provide anything to support ICEM programs to finance resettlement." 11 In mid-1975 the US government agreed to receive 400 refugees from the Southern Cone, but the strict screening procedures delayed the resettlement process and limited the number of refugees actually admitted to US soil. ${ }^{12}$ As a consequence of the US policy, most refugees relocated themselves within the

(C) Thais Bessa, 2009. This open-access work is licensed under a Creative Commons Attribution-NonCommercial 4.0 International License, which permits use, reproduction and distribution in any medium for non-commercial purposes, provided the original author(s) are credited and the original publication in Refuge: Canada's Journal on Refugees is cited. 
region and external resettlement was an option for few of them. By the end of the 1970s some 15,000 South American refugees were resettled in forty-four countries, mostly in Western Europe. ${ }^{13}$

The third refugee crisis during the late 1970s and the 1980s, in Indochina, turned out to be the largest and most expensive resettlement operation in history. Due to struggles between Communist revolutionaries and US-supported counter-revolutionaries, millions of Vietnamese, Laotians, and Cambodians were caught amidst fire and displaced. Neighbouring countries such as Thailand and Malaysia were overwhelmed with the so-called "boat people" and urged Northern support to address the situation, mainly through resettlement. The US was the leading country to support the assistance and resettlement of Indochinese refugees, since such an operation was perceived as emblematic in the context of the "new Cold War" in the early 1980s. ${ }^{14}$ Furthermore, American society was particularly sensitive to the issue of Vietnamese refugees, a position increasingly voiced by rising transnational human rights networks.

Initially other Northern countries, especially in Europe, believed that the crisis was a "US problem"15 and the US struggled to convince them that resettlement was the best solution for Indochinese refugees. Even though it initially sustained the idea that repatriation would be the most adequate solution for refugees in the region, UNHCR ultimately supported this policy, promoting two international conferences in Geneva and the Comprehensive Plan of Action for Indochinese Refugees. ${ }^{16}$ As a result of this effort, by the mid-1990s some 1.3 million Indochinese refugees were resettled. ${ }^{17}$ The US was obviously the most generous country, and from just 1975 to 1985 it received some 750,000 resettled refugees. ${ }^{18}$

The three cases exemplify how resettlement of refugees was an important political instrument within Cold War politics. In the Ugandan case, resettlement countries were eager to offer support to persecuted populations as part of their effort to contain Communist expansion in Africa. In the Latin American case, resettlement was offered as a much more limited possibility, since most refugees were fleeing Western-allied regimes. Finally, receiving Indochinese refugees through resettlement was perceived as an inexorable part of Cold War politics in the region and the resettlement response was the widest possible. However, it is important to note that despite its political manipulation, conferring different levels of usage in different situation (or even within the same situation), resettlement in this period was the preferred and in some cases the only durable solution considered by major powers.

\section{The Asylum Crisis and Its Impact on Durable Solutions}

From the late 1970s and early 1980s on, Northern states' willingness to receive refugees decreased dramatically due to economic, social, and political transformations in the international scenario and domestic politics. The so-called asylum crisis brought about containment policies and a redefinition of the concepts of durable solutions and the role of resettlement.

With global economic recession, refugees and migrants in general were no longer a welcome workforce, but rather a threat to the shrinking labour market and welfare system. ${ }^{19}$ The globalization process facilitated communications and transport and also increased-and made more visiblethe gap between North and South, fostering the desire of Southern citizens to migrate. ${ }^{20}$ Refugees and asylum seekers started to arrive directly in Northern territory in mixed movements along with other migrants. Unprecedented numbers of arrivals triggered popular discontent, causing electoral pressure for restrictive measures. ${ }^{21}$ Finally, the end of the Cold War altered one of the most important foundations of the refugee regime. Without the geostrategic motivation of promoting defection from communism, governments had little interest in receiving refugees into their territories $^{22}$ and lost their main argument for gathering internal consensus and acceptance.

The asylum crisis led to new approaches to refugee issues centred on containment. There was a proliferation of measures to restrict the granting of asylum and access to territory, ${ }^{23}$ as well as an effort to contain refugee influxes in the global South as much as possible. Such new approaches affected the conceptualization and application of durable solutions in three manners. First, there was a renewed focus on in-country operations, including maintaining refugees within their regions of origin and emphasizing repatriation.

Second, international co-operation on refugee issues became increasingly problematic as Southern states were overwhelmed with the bulk of refugee flows and Northern countries had fewer incentives to offer resettlement quotas and financial resources. As asserted by Gibney, "Western states claim that refugees in the South were too numerous to be assisted through resettlement schemes and, in any respect were not fleeing persecution (...)."24

Finally, as the numbers of asylum seekers increased, there was a general perception that Northern states lost control over refugee arrivals, especially in comparison with resettlement programs implemented in preceding years. ${ }^{25}$ The arrival of asylumseekers is spontaneous and unpredictable, in opposition to organized and predictable resettlement programs, through which governments may literally

(C) Thais Bessa, 2009. This open-access work is licensed under a Creative Commons Attribution-NonCommercial 4.0 International License, which permits use, reproduction and distribution in any medium for non-commercial purposes, provided the original author(s) are credited and the original publication in Refuge: Canada's Journal on Refugees is cited. 
chose which refugees they want to receive, how many, and when. ${ }^{26}$ In theory resettlement could be an opportunity for states to regain their lost control over refugee issues, but in light of decreasing external incentives and domestic pressure, resettlement needed to be re-shaped as a more precise and explicitly protection-oriented tool in order to maintain its role as a durable solution.

\section{(Re)defining Durable Solutions and Resettlement: A Protection Tool?}

A major consequence of the asylum crisis was a redefinition of the concept of durable solutions and the relationship between them. It was not a formal process but rather an almost natural outcome of states' policies and practices. In the post-Cold War order with low incentives for NorthSouth co-operation resettlement was no longer the preferred durable solution for refugees. In that sense, since the late 1980 s voluntary repatriation emerged as the natural and most adequate solution for most situations of displacement. Such a position was actively promoted by UNHCR, in line with the political agenda of major powers who wanted to maintain refugees in their regions of origin. Former High Commissioner Sadako Ogata had a crucial role in this approach and UNHCR established an explicit hierarchy of durable solutions ${ }^{27}$ and went as far as to declare the 1990s as "the decade of voluntary repatriation." Indeed, from 1991 to 1996 some 9 million refugees were repatriated, compared to only 1.2 million during the period $1985-1990 .{ }^{28}$ However, this approach received extensive criticism, including the criticism that UNHCR was drifting away from its original protection mandate ${ }^{29}$ and that the levels of voluntariness could be highly debated in several repatriation operations. ${ }^{30}$

While in-country operations and repatriation gained greater relevance, the discourse around the use of resettlement became somewhat conservative. In the process of redefining durable solutions, resettlement was increasingly seen as costly in terms of resources and cultural adaptation, which in technical terms is true, although such concern was never an issue during the precedent "resettlement period." ${ }^{31}$ During its $42^{\text {nd }}$ Session in 1991, the UNHCR's Executive Committee (ExCom) approved its first conclusion on international protection dealing solely with resettlement, which established a hierarchy between durable solutions: "UNHCR pursues resettlement only as a last resort, when neither voluntary repatriation nor local integration is possible, when it is in the best interests of the refugees and where appropriate." 32

Moreover, it was explicitly recognized that in preceding decades resettlement was more a migration program than a protection tool. This was made clear during the same ExCom meeting in 1991, when High Commissioner Ogata affirmed that differently from massive resettlement operations experienced during the 1980s and the previous decades, resettlement operations in the 1990s were "likely to be more protection oriented and could often involve smaller numbers." 33 . Therefore, in response to the decrease in immigration-driven resettlement, UNHCR started to apply its own protection-related criteria for a more diverse, although numerically limited, group of refugees. ${ }^{34}$ Compared with voluntary repatriation, from 1997 to 2006, for each refugee resettled, fourteen were repatriated. ${ }^{35}$

However, aware that such strong statements could create an idea that resettlement was a less important or effective solution and jeopardize its very existence, ExCom members and UNHCR toned down their approach. Later declarations emphasized that for some refugees at high risk in the country of first asylum and where repatriation is not a possibility, resettlement can in fact provide the most adequate form of protection. UNHCR publicly declared that the reduction in the number of refugees resettled during the early 1990s was mainly due to the conclusion of its operations in Southeast Asia and did not "reflect any fundamental change in the criteria which UNHCR uses to identify candidates for resettlement." 36

The emergence of new refugee crises in different parts of the world during the 1990s revealed that resettlement could still have an important role in the post-Cold War order. However, in a scenario where Northern countries had few incentives to receive refugees and to cooperate with overwhelmed Southern countries of first asylum, resettlement had to be reshaped and adapted to these new circumstances if it were to maintain its relevance. This effort was primarily led by UNHCR and focused on reinvigorating resettlement in a new context, emphasizing its protection role over political usage and offering incentives for states' co-operation.

Therefore, the concept was developed that resettlement would serve a three-fold purpose: durable solution, protection tool, and instrument of international solidarity. First, resettlement as a durable solution means that in some cases when there is continued cross-border persecution, extreme impediments to local integration, and impossibility of repatriation, resettlement is the best or even the only viable solution for refugees. Thus, resettlement should be an integral part of the comprehensive set of responses applied to each refugee situation, along with the other durable solutions. Such an approach relates to the strategic use of resettlement, which refers to its ability to benefit other refugees beyond those being resettled, as well as the host and neighbouring states. As large refugee populations challenge socio-economic structures and regional stability, resettlement can be an important means to alleviate the pressure on countries of first asylum.

(C) Thais Bessa, 2009. This open-access work is licensed under a Creative Commons Attribution-NonCommercial 4.0 International License, which permits use, reproduction and distribution in any medium for non-commercial purposes, provided the original author(s) are credited and the original publication in Refuge: Canada's Journal on Refugees is cited. 
Second, resettlement as a protection tool implied a greater focus on the individual needs of refugees rather than states' political and economic interests. To that end, resettlement should be based on well-defined criteria and required important changes in procedures. Precise criteria to assess refugees' need for resettlement were established, namely: legal and physical protection needs (including threat of refoulement), lack of integration prospects, survivors of violence and torture, women at risk, children and adolescents (especially unaccompanied minors), older refugees, medical needs, and family reunification. As the establishment of such criteria consolidated the transformation of resettlement from immigration to protection-driven, resettlement procedures also changed, evolving from mechanical group processing to case-by-case assessments.

Finally, resettlement is an instrument of international solidarity and burden/responsibility-sharing, as it offers support to overwhelmed first countries of asylum, especially in situations of protracted displacement. Since the mid-1990s UNHCR has led initiatives to encourage tripartite co-operation between the agency, states, and civil society organizations. As a result, a Working Group on Resettlement and a formal process of consultation with governments and NGOs were established in 1995. Such consultations were held on a yearly base and in 2001 it was renamed Annual Tripartite Consultations on Resettlement (ATC).

A major initiative aiming at promoting incentives for international co-operation, especially North-South, was the Convention Plus process, lead by UNHCR between 2001 and 2005. The strategic use of resettlement was one of the three topics in which multilateral agreements were sought. A Core Group was established in Geneva under the leadership of the government of Canada, which gathered states, concerned international organizations, and civil society entities. Although the initiative did not reach the intended "generic agreements," the resettlement strand was considered the most successful one, because it provided a Multilateral Framework of Understandings, even though this concrete outcome was considered a "modest and uncontroversial statement." 37

\section{A New Paradigm? Resettlement in the Post-Cold War Era}

Although it has undergone some changes in its concept and positioning $v i s-\grave{a}-v i s$ the other durable solutions available to refugees, it is unquestionable that resettlement remains an important and integral part of the refugee protection regime. It continues to benefit a large number of refugees yearly and to be the subject of discussion in different international fora and academic circles. However, how does resettlement in the post-Cold War order differ from resettlement in previous years?
Resettlement in this new context can be said to have three main characteristics. The first one refers to its concept. Throughout the 1990s and 2000s resettlement has been precisely defined in international instruments which, although non-binding, enabled a more harmonized and predictable use. Resettlement now has precise criteria, procedures, and definition of the roles of actors involved. However, maybe the most significant change in the conceptualization of resettlement has been its depoliticization. While defining its threefold purpose, resettlement has been detached from its previous political and immigration-driven use and redefined in exclusive terms of protection instrument.

Second, compared with previous decades, resettlement has in fact numerically decreased. In 1979, resettlement was the solution for one in every twenty refugees but by 1996, the proportion was one in every four hundred. ${ }^{38}$ This trend can still be observed as the total number of resettled refugees in 2006 was 11 per cent lower than in the previous year. As previously discussed, defining resettlement as a protection tool essentially means serving smaller numbers of refugees, since criteria and procedures are refined. Better screening procedures have also become an increased concern because of fraud and misuse, ${ }^{39}$ especially after the 1999 resettlement scandal in Kenya.

However, other factors also explain the reduced numbers of resettlement in the present context. Confronted by large numbers of asylum seekers arriving directly in their territories, Northern states have offered fewer resettlement places, in an attempt to "balance" the total number of refugees. This often implicit correlation between resettlement and asylum policies can be exemplified by the fact that adding resettlement and direct arrivals, the US and Western Europe admit roughly the same number of refugees, even though the US has a stronger resettlement program. ${ }^{40}$

Following 9/11 and the Global War on Terror, refugee policies are increasingly in line with security concerns, which has also affected the number of refugees admitted through resettlement. For instance, the US government has applied tighter screening procedures in its resettlement programs and therefore it has struggled to fulfill its annual resettlement quotas. This is the case especially for refugees from the Middle East and refugees that allegedly support Washington-determined "terrorist organizations" such as Colombian or Sri Lankan refugees. For instance, for fiscal year 2008 the US has established a ceiling (quota) of 70,000 refugees, but had only received 48,282 (68.9 per cent). ${ }^{41}$

Finally, the third characteristic of resettlement in the post-Cold War order is its geographic expansion beyond the traditional resettlement countries. Traditionally there were ten resettlement countries which offered annual resettlement quotas $^{42}$ and other countries offered resettlement

(C) Thais Bessa, 2009. This open-access work is licensed under a Creative Commons Attribution-NonCommercial 4.0 International License, which permits use, reproduction and distribution in any medium for non-commercial purposes, provided the original author(s) are credited and the original publication in Refuge: Canada's Journal on Refugees is cited. 
places answering ad hoc UNHCR appeals. Expanding and diversifying resettlement opportunities were a crucial part of the 1990s Alexander Betts (2008) 'Towards a "Soft Law" Framework for the Protection of Vulnerable Migrants,' New Issues in Refugee Research, Working Paper 162, UNHCR, Geneva effort to redefine resettlement as a protection tool and instrument of international co-operation.

Following UNHCR consultations, since 1996 seven new countries have established resettlement programs, although only five remain operative. Although two countries are from the global North (Iceland and Ireland), the main innovation is the emergence of Southern countries of resettlement. Between 1998 and 2001 Benin and Burkina Faso received 226 refugees, mainly from other African countries. However, a 2003 evaluation found overall "disappointing results" 43 and the program in both countries was discontinued.

Despite the unsuccessful pilot project in Africa, UNHCR further promoted other resettlement initiatives in the global South, focusing on Latin America. Since 2002 and until the end of 2007, Brazil, Chile, and Argentina have received some 1,000 resettled refugees. ${ }^{44}$ The program in such countries remains operative and it has already expanded beyond its initial scope: although the main beneficiaries of the resettlement program in Latin America are Colombian refugees, some 100 Palestinian refugees have also been admitted.

\section{Explaining the Continued Use of Resettlement}

It has been argued that despite its reduced numbers and a new façade, resettlement is still an important part of the protection regime. However, an important question should be asked regarding its continued use: if the Cold War interests no longer exist and Northern states are increasingly unwilling to receive refugees, why do they keep resettling?

First of all, UNHCR's catalytic role must be recognized. Although the agency has followed states' political interest in replacing voluntary repatriation as the preferred durable solution, it has also remained aware of the importance resettlement has in several refugee situations. As new refugee crises erupt worldwide and in a context of increasing containment, it is important that resettlement remains an option of safe haven to refugees. Nevertheless, aware that incentives for international co-operation and provision of resettlement have changed since the end of the Cold War, UNHCR has attempted to offer alternative incentives, mostly by detaching resettlement from its previous clear political and immigration nature and redefining it as an exclusive political tool. This official depoliticization of resettlement would ensure that states remain committed to it.

Second, as mentioned before, with the asylum crisis there was a generalized perception that Northern states have lost control over the entry of immigrants and refugees. For these governments, resettlement is a means to uphold their international commitments towards refugee protection while maintaining their control over which refugees are admitted, how many, and when. Hence, the offer of resettlement has been used to justify stricter policies regarding admission and the granting of asylum. Furthermore, resettlement is useful to reinforce to the domestic public the idea that resettlement and asylum are totally different areas of refugee protection. For instance, the US maintains two strictly different concepts that embody distinct normative and institutional frameworks. "Refugee" refers to a resettled refugee and "asylee" or "asylum-seeker" to a person claiming protection directly on US soil. ${ }^{45}$ Similarly, in Western Europe, resettlement has been used to clarify and legitimize the distinction between "true" and "bogus" refugees. ${ }^{46}$

Finally, although the asylum crisis reduced Northern states' willingness to receive refugees and immigrants in general, no country so far has applied a strict no-entry policy. Continued refugee admissions can be explained by a complex combination of several interests, such as humanitarian concerns and domestic pressure, as well as economic, political, and foreign policy interests.

States have a humanitarian interest in admitting refugees according to their international commitments as signatories of international instruments such as the 1951 Refugee Convention. In most cases, such commitments have been internalized by domestic legislation and compliance with them is overseen by national and regional courts. Nevertheless, this humanitarian concern has a limited role, since states often circumvent their international obligations by preventing access to territory or creating new categories and concepts. ${ }^{47}$ The inconsistent offer of resettlement to different refugee populations also reveals that humanitarian concerns have only marginally influenced resettlement programs.

Pressure from domestic groups and economic interests have also influenced states' refugee policies. ${ }^{48}$ Resettlement admissions can be influenced by lobby groups from refugee populations already present in the country or by economic groups interested in attracting or avoiding specific skills. In a broader sense, the domestic public also influences immigration and refugee policies through electoral pressures.

Finally, although resettlement has been redefined as a protection tool disentangled from political interests, they still play a crucial role in determining whether resettlement will be applied, to which populations, and to what extent. In that sense, little has changed from Cold War period. For instance, the main category of refugees admitted for resettlement in the US is comprised of those falling within certain ethnic groups and/or country of first asylum. ${ }^{49}$ Although in consultation with other actors, the Department of State is 
responsible for deciding which groups are included in the annual resettlement quota, which demonstrates the highly political character of such decisions.

\section{Critical Analysis and Final Remarks}

Beyond debates on manipulation of resettlement policies, it is fundamental to recognize the generosity of Northern states. It is undeniable that resettlement has been a lifechanging or even life-saving instrument for many refugees throughout history. Since the late 1970s, more than 250,000 refugees have been admitted in Western Europe through UNHCR-led resettlement operation $\mathrm{s}^{50}$ and the US alone has resettled over two million refugees, more than all other resettlement countries together. ${ }^{51}$

Resettlement depoliticization during the 1990s and 2000 s enabled it to remain relevant in the refugee protection regime. Its redefinition had positive effects, especially bringing more transparency to the process with the establishment of precise criteria and procedures. The focus on solidarity and responsibility-sharing may offer an opportunity to enhance international co-operation (especially North-South) in other areas of refugee protection.

However, if this depoliticization had positive impacts, some critical observations must be made. First of all, it is important to bear in mind the motives behind the redefinition of resettlement from a political instrument to a protection tool. As UNHCR led this effort, it was responding to new interests and political relations between states, adapting resettlement to a political context characterized by containment and decreased incentives for international co-operation. It can be said then that the depoliticization process was essentially politically motivated.

Furthermore, the extent to which this depoliticization is real is also debatable. As demonstrated before, despite the exclusive protection facade adopted after the end of the Cold War, resettlement programs are still discretionary and respond to a set of concerns and interests that go far beyond their strict use as a protection tool. This is corroborated by the inconsistent application of resettlement policies towards different refugee policies and states' difficulties in fulfilling annual resettlement quotas. For instance, in 2006 some 29,600 refugees were resettled through UNHCR programs and a further 71,700 were resettled outside the agency, ${ }^{52}$ which demonstrates that traditional resettlement countries still keep a largely discretionary policy regarding resettlement and prefer to maintain their own channels and agencies, using UNHCR only to some extent.

Another important question refers to how the new approach to resettlement fits into North-South politics. Despite the non-political discourse, resettlement is deeply entangled in containment policies. The concept of strategic use of resettlement may conceal the interest in maintaining refugees in their regions, not to facilitate future repatriation, but rather to avoid their further movement to Northern countries. Besides, according to van Selm, especially in Europe several actors have tried to "sell" resettlement as a tool to reduce the arrival of asylum-seekers, ${ }^{53}$ which represents a great risk not only of resettlement misuse, but to the integrity of the protection regime.

The emerging resettlement programs in the global South also deserve a critical analysis. Southern countries already host the majority of refugees in the world, but under an international solidarity discourse they are assuming yet another obligation through resettlement. Although Southern resettlement countries receive a much smaller number of refugees, the initiative reveals that the level of responsibility sharing and international co-operation in refugee issues is still unfair and needs to be further developed.

It is interesting then to argue why Southern countries join such initiatives. Their incentives include increased international visibility and prestige, promoted by the catalytic role of UNHCR. The financial cost to these governments is very limited, as the programs are almost fully funded by UNHCR and Northern countries, which imposes challenges regarding ownership and long-term sustainability. The countries with most successful programs are those with medium levels of economic development and small numbers of refugees in general, which also raises the questions of feasibility and sustainability of resettlement in Southern countries lacking adequate levels of economic development and resources. Furthermore, an external and comprehensive evaluation of the resettlement programme in Latin America has not yet been conducted and its accurate level of success is still unknown.

The real interests of Northern countries in supporting resettlement in developing countries can also be questioned. As mentioned, promoting intra-regional resettlement may corroborate broader containment strategies to avoid further refugee movements heading North. As Southern resettlement programs are financially and conceptually supported by UNHCR and Northern states, it is important that this is not perceived as an excuse to decrease international cooperation or as Northern countries "paying" to resettle refugees away from their territories in order to avoid domestic pressures.

In conclusion, some fundamental challenges are still to be addressed by resettlement in the present context. In a general environment of containment, the number of official refugees is declining as the number of Internally Displaced People (IDPs) and others in need of international protection increases. Given the current legal and institutional frameworks, resettlement is not a viable option for most of these

(C) Thais Bessa, 2009. This open-access work is licensed under a Creative Commons Attribution-NonCommercial 4.0 International License, which permits use, reproduction and distribution in any medium for non-commercial purposes, provided the original author(s) are credited and the original publication in Refuge: Canada's Journal on Refugees is cited. 
populations, even though it could be the best or only solution in several cases.

Finally, resettlement is still not an effective protection tool for protracted displacement situations. Even when a displacement crisis initially received support from Northern countries through resettlement places, this willingness tends to decline over time and large populations remain in a deteriorating situation. Those refugee groups that have little political leverage or that have long been forgotten by the media and donors are likely to remain in a situation of limbo, as resettlement remains a forgone option.

\section{Notes}

1. The International Thesaurus of Refugee Terminology (ITRT) was established as an information resource by UNHCR in 1988. Since 2002, an online version is co-ordinated by UNHCR and Forced Migration Online (FMO); see <http:// www.refugeethesaurus.org $>$ (accessed October 12, 2009).

2. James Hathaway, The Law of Refugee Status (Toronto: Butterworths, 1991).

3. Mathew Gibney and Randall Hansen, "Asylum Policy in the West: Past Rrends, Future Possibilities" (paper, prepared for presentation at the Wider International Conference on Poverty, International Migration and Asylum, Helsinki, September 27-28, 2002).

4. Gil Loescher, UNHCR and World Politics: A Perilous Path, (Oxford: Oxford University Press, 2001).

5. United Nations High Commissioner for Refugees (UNHCR), The State of the World's Refugees: Fifty Years of Humanitarian Action.(Oxford, Oxford University Press, 2000).

6. Ibid.

7. Ibid, 152 .

8. Ibid.

9. Ibid.

10. Jayme Esponda Fernandez, "La tradición latinoamericana de asilo y la protección internacional de los refugiados," in El asilo y la protección Internacional de los refugiados en América Latina: Análisis crítico del dualismo "asilo-refugio" a la luz del derecho internacional de los derechos humanos, ed. Leonardo Franco (San Jose: ACNUR, Editorama, 2004), 79-124.

11. Loescher, 171.

12. Ibid.

13. Gary Troeller, "UNHCR resettlement: evolution and future direction," International Journal of Refugee Law, 2002, 14, no. 1: 85-95.

14. UNHCR.

15. Loescher.

16. Alexander Betts, "Comprehensive Plans of Action: Insights from CIREFCA and the Indochinese CPA," New Issues in Refugee Research, Working Paper No. 120 (Geneva: UNHCR, 2006).
17. Astrid Suhrke, "Uncertain Globalization: Refugee Movements in the Second Half of the Twentieth Century," in Global History and Migrations, ed. W. Gungwu (Boulder, CO): Westview Press, 1997), 217-239.

18. Loescher.

19. Khalid Koser, "New Approaches to Asylum?" International Migration 39, no. 6 (2001): 85-101.

20. Stephen Castles, "Towards a Sociology of Forced Migration and Social Transformation," Sociology 37 (2003): 13-34.

21. Mathew Gibney, "The State of Asylum: Democratization, Judicialization and Evolution of Refugee Policy in Europe," New Issues in Refugee Research, Working Paper No. 50 (Geneva: UNHCR, 2001).

22. Koser.

23. Ibid.

24. Gibney, 5.

25. Loescher.

26. Jeff Crisp and Damtew Dessalegne, "Refugee Protection and Migration Management: The Challenge for UNHCR," New Issues in Refugee Research,Working Paper No. 64 (Geneva: UNHCR, 2002).

27. Jeff Crisp, "The Local Integration and Local Settlement of Refugees: A Conceptual and Historical Analysis," New Issues in Refugee Research, Working Paper No.102 (Geneva: UNHCR, 2004).

28. Loescher.

29. Michael Barutciski, "A Critical View on UNHCR's Mandate Dilemmas," International Journal of Refugee Law 14, no. 2-3 (2002): 365-38

30. B.S. Chimni, "From Resettlement to Involuntary Repatriation: Towards a Critical Story of Durable Solutions to Refugee Problems," New Issues in Refugee Research, Working Paper No. 2 (Geneva: UNHCR, 1999).

31. Ibid.

32. UNHCR Executive Committee, Conclusion $N^{\circ} 90$ (LII) Conclusion on International Protection, A/AC.96/673. (Geneva: UNHCR, 1991) [emphasis added].

33. UNHCR Resettlement Section, "Resettlement: An Instrument of Protection and a Durable Solution," Opinion, International Journal of Refugee Law 9, no. 4 (1997): 666673.

34. Gary Troeller, "UNHCR Resettlement as an Instrument of International Protection: Constraints and Obstacles in the Arena of Competition for Scarce Humanitarian Resources," International Journal of Refugee Law 3, no. 3 (1991): 564578.

35. United Nations High Commissioner for refugees (UNHCR), Statistical Yearbook 2006: Trends in Displacement, Protection and Solutions, (2006), <http://www.unhcr.org/statistics/ STATISTICS/478cda572.html> (accessed October 12, 2009).

36. UNHCR Resettlement Section.

37. Alexander Betts and Jean-Francois Durieux, "Convention Plus as a Norm-Setting Exercise," Journal of Refugee Studies 20, no. 3 (2007): 509-535; at 514. 
38. Troeller, "UNHCR Resettlement."

39. Davis Martin, The United States Refugee Admissions Program: Reforms for a New Era of Refugee Resettlement (Washington, DC: Migration Policy Institute, 2005); Gregor Noll and Joanne van Selm, Rediscovering Resettlement, Insight № 3 . (Washington: Migration Policy Institute, 2003).

40. Noll and van Selm.

41. US Department of State, "Summary of Refugee Admissions for Fiscal Year 2008," <http://www.state.gov/documents/ organization/120385.pdf> (accessed October 12, 2009).

42. Australia, Canada, Denmark, Finland, the Netherlands, New Zealand, Norway, Sweden, US, and Switzerland.

43. Steven Sperl and Irinel Brădişteanu, Refugee Resettlement in Developing Countries: The Experience of Benin and Burkina Faso, 1997-2003. An independent evaluation. (Geneva: UNHCR Evaluation and Policy Analysis Unit and Resettlement and Special Cases Section, EPAU/2004/04Rev.1, 2004), 7.

44. United Nations High Commissioner for Refugees (UNHCR), UNHCR Global Report 2006, (2007), <http:// www.unhcr.org/publ/3b7b87e14.html> (accessed October 12, 2009).

45. Erin Patrick, The US Refugee Resettlement Program, Migration Information Source (2003), <http://www. migrationinformation.org/USfocus/display.cfm?ID=229> (accessed October 12, 2009).
46. Troeller, "UNHCR Resettlement."

47. Gibney.

48. Noll and van Selm.

49. Joanne van Selm, "The Strategic Use of Resettlement: Changing the Face of Protection?" Refuge 22, no. 1 (2004), 39-48.

50. Jeff Crisp, "Policy Challenges of the New Diasporas: Migrant Networks and Their Impact on Asylum Flows and Regimes," New Issues in Refugee Research, Working Paper No. 7 (Geneva: UNHCR, 1999).

51. Patrick.

52. UNHCR, Statisticial Yearbook 2006.

53. Van Selm.

Thais Bessa has an M.Sc. in Forced Migration from the University of Oxford and has worked for UNHCR and UNIFEM for several years. A former Visiting Fellow at the Refugee Studies Centre, University of Oxford, she is now an independent researcher working on forced migration in South America and protracted displacement.

The author would like to thank the two anonymous reviewers for valuable input, as well as Alexander Betts and Benjamin Mackenzie-Grieve for their comments to an earlier version of this article. 